\title{
THE APPLICATION OF DISCUSSION METHOD TO IMPROVE UNDERSTANDING ON INDONESIA REGION
}

\section{PENERAPAN METODE DISKUSI UNTUK MENINGKATKAN PEMAHAMAN WILAYAH INDONESIA}

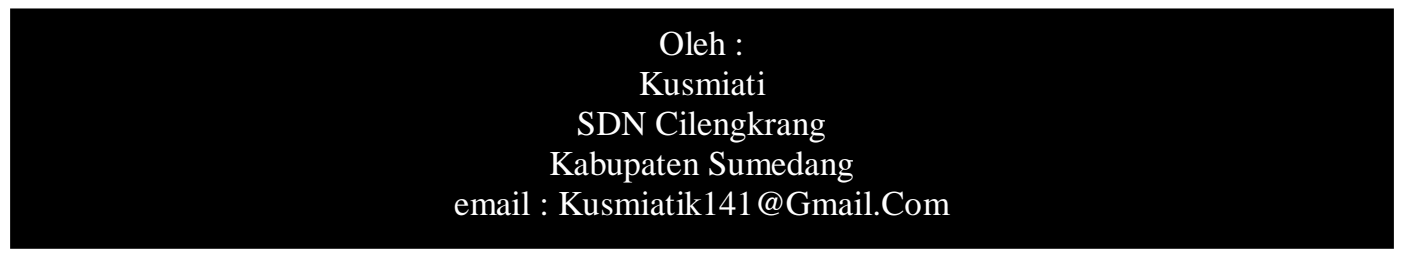

Abstract, Social science subject is a subject that is open and growing in nature. This study aimed to describe the application of discussion method to improve students' learning outcomes in the basic competencies of Indonesia region natural appearance at Grade $V$ SDN Cilengkrang North Sumedang District of Sumedang Regency in 2014/2015 academic year. This study used action research method with two cycles. The data was analysed using comparative descriptive analysis technique by comparing the initial condition to the outcomes achieved in every cycle while qualitative descriptive technique was used to compare observation data to reflections in cycle I and II. The results showed that at the end of cycle II, there was an increase of $3.33 \%$ on the class average grade, from 67.7 to 71.08 while the minimum mastery criteria increased by $7 \%$ from 11 students to 18 students. Hence, most of grade $V$ students had improved their learning outcomes in the basic competencies of Indonesia region natural appearance.

Keywords: discussion method, social science, learning outcomes

Abstrak, Mata pelajaran Ilmu Pengetahuan Sosialmerupakan mata pelajaran yang sifatnya terbuka dan berkembang. Penelitian ini bertujuan untuk mendiskripsikan penerapan Metode Diskusi untuk meningkatkan hasil belajar pada Kompetensi Dasar Kenampakan Alam Wilayah Indonesia Pada Siswa Kelas 5 SD Negeri Cilengkrang Kecamatan Sumedang Utara Kabupaten Sumedang Tahun Pelajaran 2014/2015. Metode penelitian yang digunakan yaitu Penelitian Tindakan Kelas dengan metode diskusi yang terdiri atas 2 siklus. Analisis data menggunakan teknik analisis diskriftif komparatif dengan membandingkan kondisi awal dengan hasil-hasil yang dicapai pada setiap siklus,dan analisis deskriftif kualitatif hasil observasi dengan membandingkan hasil observasi dan refleksi pada siklus I dan siklus II. Pada akhir siklus II diketahui peningkatan rata-rata kelas $3,33 \%$ dari rata-rata tes kondisi awal 67,75 menjadi 71,08 ,sedangkan pada ketuntasan belajar siswa terdapat peningkatan sebesar $7 \%$ dari tes kondisi awal yang sudah tuntas hanya 11 siswa menjadi 18 siswa.Dengan demikian sebagian besar siswa kelas 5 mengalami peningkatan hasil belajar pada Kompetensi Dasar kenampakan alam wilayah Indonesia.

Kata Kunci: metode diskusi, ilmu pengetahuan sosial, hasil belajar

\section{A. PENDAhUluan}

Proses pembelajaran yang

menyenangkan merupakan salah satu

faktor yang dapat menunjang

keberhasilan suatu pembelajaran karena ketika pembelajaran itu di lakukan dengan cara yang menyenangkan, maka materi yang di pelajari akan mudah di terima dan di mengerti dengan baik oleh siswa. 
Untuk mengatasi pembelajaran IPS agar tidak monoton dan lebih bervariasi, maka dapat di gunakan media pembelajaran.

Kejenuhan dalam pembelajaran IPS akan membuat siswa kurang fokus dalam belajar. Ketika siswa jenuh, siswa lebih memilih hal-hal yang menurut mereka lebih menyenangkan, seperti mengobrol dengan temannya atau juga asik dengan imajinasinya sendiri. Hal seperti itu akan berpengaruh terhadap penguasaan materi pelajaran. Siswa tidak akan menyerap apa yang akan di paparkan oleh guru apa bila keadaan siswanya tidak dalam keadaan siap belajar.

Dalam pembelajaran di kelas, guru IPS kurang menggunakan metode pembelajaran yang bervariasi dan masih kurang menggunakan metode diskusi di dalam kelas. Ada beberapa metode pembelajaran yang harus divariasikan oleh guru di kelas, misalnya tanya jawab, kartu berpasangan, mind mapping dan lain sebagainya. Metode pembelajaran yang diterapkan oleh guru sudah baik, namun masih kurang menggali kemampuan siswa untuk menemukan ide-ide baru dan berdiskusi.
Pembelajaran IPS yang masih jarang menggunakan kegiatan diskusi, bukan merupakan masalah utama dalam proses pembelajaran di kelas. Ada berbagai macam masalah yang sering dialami oleh guru IPS di dalam kelas, misalnya siswa belum aktif di dalam kelas yang ditandai dengan siswa jarang mengeluarkan pendapat maupun bertanya, siswa ribut sendiri bersama temannya saat proses pembelajaran, dan siswa belum aktif dalam kegiatan kelompok.Belum lagi jika guru tidak memahami dengan jelas isi dari materi yang akan disampaikan. Karena Salah satu komponen pendukung bagi keberhasilan peningkatan mutu pendidikan IPS adalah Kompetensi Pedagogik dan profesionalisme guru merupakan kompetensi yang mutlak perlu dikuasai guru. Kompetensi pedagogik pada dasarnya adalah kemampuan guru dalam mengelola pembelajaran peserta didik.

Untuk membuat siswa bisa aktif, guru disini sangat berperan karena di usahakan seorang guru harus bisa mengkondisikan siswanya untuk bisa terlibat aktif dalam diskusi kelas dan di usahakan murid harus dalam kondisi yang siap menangkap semua pelajaran 
yang akan di bahas di dalam kelas. Disini guru di tuntut untuk bisa meningkatkan kualitasnya, menurut Depdiknas (2005) peningkatan kualitas guru dapat dilihat dari kinerjanya. beberapa indikator kualitas perilaku pembelajaran guru dapat dicermati antara lain pada: (1) Kemampuan guru dalam membangun perspepsi dan sikap positif siswa terhadap belajar; (2) Penguasaan ilmu yang luas dan mendalam serta mampu memilih, menata, mengemas, dan menyajikan materi sesuai kebutuhan siswa; (3) Kemampuan memahami keunikan setiap siswa dengan segenap kelebihan dan kekurangannya; (4) Kemampuan memahami lingkungan keluarga, sosial budaya, dan kemajemukan masyarakat tempat kehidupan siswa;

Kemampuan mengelola pembelajaran yang mendidik berorientasi pada siswa yang tercermin dalam kegiatan merencanakan, melaksanakan, dan mengevaluasi pembalajaran secara dinamis untuk membentuk kompetensi siswa; (6) Kemampuan mengembangkan kepribadian dan keprofesionalan secara berkelanjutan.

IPS merupakan mata pelajaran yang mempelajari kehidupan sosial yang didasarkan pada bahan kajian geografi, ekonomi, sosiologi, antropologi, tatanegara dan sejarah yang bertujuan untuk mengembangkan pengetahuan dan keterampilan dasar yang berguna bagi dirinya dalam kehidupan sehari- hari. Seorang guru yang kreatif dapat dilihat pada saat mengajar pelajaran IPS. Tidak selamanya materi IPS dapat diceritakan dan dihafalkan, melainkan harus menggunakan nalar dan intelegensi yang tinggi seperti belajar tentang geologi, geomorfologi, kosmografi. Tanpa berfikir yang rasional dan nalar yang tinggi sangat sulit mengerti tentang bahan kajian tersebut. Tidak hanya pelajaran eksak yang menjad tolak ukur kecerdasan siswa pelajaran IPS pun dapat dijadikan tolak ukur, karena siswa yang cerdaslah yang dapat menelaah, menganalisa, dan mengambil suatu kesimpulan terhadap suatu peristiwa sosial yang terjadi di masyarakat.

Siswa kelas V SD lebih mudah untuk diajarkan sebuah materi disertai praktek langsung di lapangan. Sehingga dalam benak para siswa tersebut akan terbentuk gagasan tentang pembagian wilayah waktu di Indonesia, karena adanya pembelajaran Model ceramah yang diberikan dan 
memahami konsep tersebut Lingkungan sebagai sumber berdasarkan pengalaman pribadi. pembelajaran menuntut kreatifitas guru Belajar merupakan peristiwa sehari - untuk memanfaatkan dan hari di sekolah. Belajar merupakan hal mengeliminasi kebiasaan mengajar yang kompleks. Kompleksitas belajar yang rutinitas dan tersebut dapat dipandang dari dua monoton.Memanfaatkan lingkungan subjek, yaitu dari siswa dan guru. Dari sebagai sumber belajar dapat segi siswa, belajar dialami sebagai menciptakan suasana belajar yang aktif suatu proses. Siswa mengalami proses dan kreatif atau PAIKEM serta mental dalam menghadapi bahan mengembangkan kemampuan berpikir belajar. Bahan belajar tersebut berupa logis dan sistematis .Karena dari keadaan alam, hewan, tumbuh- lingkungan muncul fenomena yang tumbuhan, manusia, dan bahan yang menarik dan menantang bagi siswa. telah terhimpun dalam buku-buku Oleh karena itu guru dituntut memiliki pelajaran. Dari segi guru, proses belajar keterampilan bisa membawa suasana tersebut tampak sebagai perilaku lingkungan ke dalam kelas dan belajar tentang sesuatu hal.

Sebenarnya guru sering melupakan sumber belajar yang terdapat dilingkungan sekitarnya ,baik di sekolah maupun di luar bawalah siswa ke luar kelas serta berilah kesempatan kepada mereka untuk belajar dengan lingkungan.

Secara umum, penelitian ini sekolah.Betapapun kecil dan terpencilnya suatu sekolah,sekurangkurangnya lingkungan mempunyai empat jenis sumber belajar yang sangat kaya dan bermanfaat bagi proses pembelajaran. Keempat sumber belajar itu antara lain: (1) masyarakat desa / kota di sekitar sekolah ; (2) lingkungan fisik sekitar sekolah; (3) bahan sisa yang bisa dimanfaatkan; dan peristiwa alam.

bertujuan untuk menganalisis aktivitas belajar siswa pada saat mata pelajaran IPS melalui metode diskusi.

Berdasarkan penyebaran data awal yang didapatkan bahwa siswa yang dapat memahami materi kenampakan alam hanya $30 \%$, sisanya $70 \%$ masih belum memahami materi tersebut. Oleh karena itu peneliti bermaksud mengkaji penerapan metode diskusi untuk meningkatkan pemahaman siswa pada materi kenampakan wilayah alam. 
Pendekatan penelitian menggunakan menguji derajat kepercayaan atau pendekatan kuantitatif. Metode derajat kebenaran penelitian tindakan penelitian yang digunakan yaitu kelas yaitu: (1) member chek, (2) penelitian tindakan kelas, dengan triangulasi, (3) audit trail, (4) expert teknik pengumpulan data berupa opinion, dan (5) key respondents angket dan tes hasil belajar siswa. review.

Analisis data menggunakan teknik

\section{B. HASIL DAN PEMBAHASAN}

member chek, triangulasi,audit trail dan expert opinion.

Metode yang tepat dan relevan dengan masalah yang dihadapi adalah melalui metode penelitian tindakan kelas (classroom action research). Desain PTK yang digunakan adalah desain Kemmis \& McTaggart (Arikunto, 2006). Desain Kemmis \& McTaggart. Instrumen yang digunakan pada penelitian ini adalah pedoman observasi, pedoman wawancara, dan lembar tes hasil belajar siswa. Analisis data pada penelitian ini dimulai dengan menelaah seluruh data yang tersedia dari berbagai sumber yang terkumpul yaitu dari hasil observasi kinerja guru dan aktivitas siswa ketika pembelajaran, tes akhir serta wawancara terhadap observer dan siswa yang dijadikan subjek penelitian.

Adapun validasi data yang digunakan yaitu menurut Hopkins (Wiriaatmadja, 2005) ada beberapa bentuk validasi yang digunakan untuk pada pembelajaran perbaikan siklus I dan siklus II,peneliti bersama teman sejawat melakukan refleksi terhadap hasil penelitian tindakan dengan maksud untuk mengetahui sejauhmana keberhasilan dan kegagalan setelah diamati,diteliti ternyata peneliti dinyatakan berhasil meningkatkan hasil belajar.Setelahtindakan diperlukan pengujian untuk membuktikan efektivitas tindakan yang diperlukan. Pada saat tes akhir ,tindakan guru memberi soal yang harus dijawab oleh seluruh siswa secara individu.Soal yang diberikan oleh peneliti adalah kajian materi pembelajaran yang telah diajarkan dengan tujuan untuk mengetahui sejauh mana penguasaan materi terhadap materi yang telah diberikan. Pembahasan difokuskan pada peninkatan kemampuan penguasaan materi pelajaran oleh siswa. 
Pada tahap tindakan hasil dari pada tes prasiklus yaitu dari 20 penguasaan materi pembelajaran yang Orang siswa $10 \quad \%$ siswa yang diperoleh siswa rata-rata kemampuan memperleh skor maximal 85 dan masih siswa $30 \%$ atau dapat dikatakan kurang $20 \%$ siswa yang memperoleh skor dari standar perolehan scor minimal 70 minimal 65,sehingga tindakan I perlu $\%$. perbaikan pada tindakan II.

Dari 20 siswa subjek penelitian , 1 Pada tes tindakan II media orang siswa ( $5 \%$ )memperoleh skor pembelajaran yang abstrak diganti 50, 4 orang siswa ( $20 \%$ ) memperoleh dengan yang kongkret untuk lebih skor 60, 4 orang siswa ( $20 \%$ ) memahami siswa terhadap materi memperoleh skor 65,6 orang siswa ( $30 \%$ ) memperoleh skor 70,3 orang siswa ( $15 \%$ ) memperoleh skor 75,2 orang siswa ( $10 \%)$ memperoleh skor 80.

Pada tindakan I,metode yang pelajaran .Hasil yang diperoleh pada siklus II lebih meningkat dibandingkan dengan nilai pada siklus I.Dengan memanfaatkan media atau alat peraga pada siklus I dan siklus II ternyata dapat meningkatkan prestasi siswa digunakan adalah tanya jawab, diskusi tentang materi kenampakan alam dan pemberian tugas,alat dan bahan wilayah Indonesia,meningkatkan minat yaitu lembar kerja siswa ,gambar belajar siswa,meningkatkan peristiwa yang disebabkan oleh pemahaman tentang materi,serta siswa alam,serta lembar evaluasi .Pada siklus lebih berani lagi mengungkapkan I kemampuan siswa lebih meningkat pendapatnya saat dikelas.

Tabel. 2.1

Hasil Evaluasi Siswa Dalam Pembelajaran IPS

\begin{tabular}{|c|c|c|c|c|}
\hline \multirow{2}{*}{ NO } & \multicolumn{3}{|c|}{ NILAI HASIL EVALUASI } & \multirow{2}{*}{ RATA } \\
\cline { 2 - 4 } & PRASIKLUS & $\begin{array}{c}\text { SIKLUS } \\
\text { I }\end{array}$ & $\begin{array}{c}\text { SIKLUS } \\
\text { II }\end{array}$ & RATA \\
\hline 1. & 65 & 70 & 75 & 70,00 \\
\hline 2. & 75 & 80 & 90 & 81,67 \\
\hline 3. & 75 & 80 & 95 & 83,33 \\
\hline 4. & 60 & 70 & 70 & 66,67 \\
\hline 5. & 70 & 75 & 80 & 75,00 \\
\hline
\end{tabular}




\begin{tabular}{|c|c|c|c|c|}
\hline 6. & 80 & 85 & 95 & 86,67 \\
\hline 7. & 70 & 75 & 85 & 76,67 \\
\hline 8. & 80 & 85 & 95 & 86,67 \\
\hline 9. & 70 & 75 & 85 & 76,67 \\
\hline 10. & 75 & 80 & 95 & 83,33 \\
\hline 11. & 65 & 70 & 85 & 73,33 \\
\hline 12. & 60 & 65 & 75 & 66,67 \\
\hline 13. & 65 & 65 & 80 & 70,00 \\
\hline 14. & 70 & 75 & 80 & 75,00 \\
\hline 15. & 65 & 65 & 80 & 70,00 \\
\hline 16. & 60 & 60 & 65 & 63,33 \\
\hline 17. & 60 & 70 & 80 & 70,00 \\
\hline 18. & 50 & 70 & 75 & 65,00 \\
\hline 19. & 70 & 75 & 85 & 76,67 \\
\hline 20. & 70 & 75 & 80 & 75,00 \\
\hline Jumlah & 1355 & 1470 & 1650 & 1421,68 \\
\hline $\begin{array}{c}\text { Rata- } \\
\text { rata }\end{array}$ & 67,75 & 73,50 & 82,50 & 71,08 \\
\hline
\end{tabular}

Berdasarkan hasil pasca tindakan, didapatkan rata-rata dari siklus kesatu sebesar 73,50, dan siklus kedua sebesar 82,50. Dalam hal ini terlihat dinamika perubahannya. Siswa sudah dapat memahami materi kenampakan wilayah alam. Dari data tersebut diketahui hasil evaluasi yang didapat pada mata pelajaran IPS adalah sebagi berikut. Selama proses belajar mengajar berlangsung teman sejawat melakukan pengamatan terhadap kegiatan pembelajaran yang yang dilakukan oleh peneliti.

Dalam penelitian Oki Rudy (2009) menyimpulkan bahwa dengan metode diskusi dapat meningkatkan proses belajar IPS mulai dari tahap prasiklus sebesar 54,51 selanjutnya pada siklus I diperoleh hasil 67,74 dan pada siklus II sebesar 80,96. Hal ini sesuai dengan penelitian yang dilakukan, bahwa metode diskusi terbukti efektif untuk meningkatkan pemahaman materi kenampakan wilayah Indonesia pada mata pelajaran IPS.

Hal ini didukung oleh penelitian oleh Lestari (2010) yang menjelaskan tentang metode diskusi sangat cocok pada mata pelajarn IPS dengan hasil belajar siswa yang menunjukkan peningkatan pada tahap prasiklus ke siklus I dan ke siklus II meningkat sebesar 64\%, 76\%, hingga $88 \%$.

Berdasarkan pemaparan diatas, penerapan metode diskusi pada mata 
pelajasan IPS dengan materi mempermudah pemahaman siswa kenampakan wilayah alam Indonesia terhadap materi pelajaran.

terbukti efektif terlihat pada setiap siklus.

\section{SIMPULAN}

Penggunaan metode diskusi terbukti efektif dapat meningkatkan pemahaman materi kenampakan wilayah alam. Hal ini dapat ditandai dengan materi pembelajaran dan karakteristik peserta didik mampu memberikan suatu pengalaman baru yang bisa merubah dan membuka pemikiran siswa, meningkatkan kemampuan siswa dalam keberanian mengemukakan pendapat,dan mengurangi kejenuhan dan kebosanan dalam pembelajaran IPS.

1. Saran

Metode diskusi dapat dijadikan sebagai salah satu alternatif dalam pembelajaran karena metode ini terbukti memiliki tingkat keberhasilan dalam meningkatkan kemampuan penguasaan materi pembelajaran kenampakan alam wilayah Indonesia. Guru hendaknya menggunakan alat dan sumber belajar yang sepenuhnya mendukung pencapaian tujuan pembelajaran ,karena dapat membantu

\section{DAFTAR PUSTAKA}

Arikunto, S. Suhardjono dan Supardi. (2006). Penelitian Tindakan Kelas. Jakarta: Bumi Aksara.

Depdiknas. (2006). Kurikulum Tingkat Satuan Pendidikan (KTSP) 2006. Jakarta: Balai Pustaka.

Lestari. (2010). Upaya Peningkatan Motivasi Belajar IPS melalui Pembelajaran Diskusi Kelompok dengan Pendekatan Sains Teknologi dan Masyarakat di Kelas IV SDN Rejosari 02 Bancak Kabupaten Semarang. Skripsi pada Jurusan PGSD FIP UNES.

Susanto, Oki R. (2009). Upaya Peningkatan Hasil Belajar IPS Melalui Pembelajaran Berbasis Diskusi Terfokus Bagi Siswa Kelas IV SDN Sinduagung, Selomerto, Wonosobo. Skripsi pada Jurusan PGSD FKIP Jember.

Zainal Akib. (2007). Penelitian Tindakan Kelas Untuk Guru. Bandung: Yrama Widya. 